This item was submitted to Loughborough's Research Repository by the author.

Items in Figshare are protected by copyright, with all rights reserved, unless otherwise indicated.

\title{
International education and the employability of UK students
}

PLEASE CITE THE PUBLISHED VERSION

http://dx.doi.org/10.1080/01411926.2010.544710

\section{PUBLISHER}

Wiley / @ British Educational Research Association

\section{VERSION}

AM (Accepted Manuscript)

\section{PUBLISHER STATEMENT}

This work is made available according to the conditions of the Creative Commons Attribution-NonCommercialNoDerivatives 4.0 International (CC BY-NC-ND 4.0) licence. Full details of this licence are available at: https://creativecommons.org/licenses/by-nc-nd/4.0/

\section{LICENCE}

CC BY-NC-ND 4.0

\section{REPOSITORY RECORD}

Brooks, Rachel, Johanna Waters, and Helena Pimlott-Wilson. 2019. "International Education and the Employability of UK Students". figshare. https://hdl.handle.net/2134/18393. 


\title{
International education and the employability of UK students
}

\author{
Rachel Brooks, Johanna Waters and Helena Pimlott-Wilson
}

\section{Published in the British Educational Research Journal, April 2012}

\section{Introduction}

A common theme within the academic literature on higher education is the congested nature of the graduate labour market and the increasingly protracted transitions from university into work (Brown and Hesketh, 2004). Researchers have highlighted the lengths to which many students now go, in response to this congestion, to 'distinguish themselves' from other graduates of a mass higher education system: paying increased attention to the status of the university (Reay et al., 2005); engaging in a range of work-relevant extra-curricular activities (Author A, 2007; Brown and Hesketh, 2004); and, on completion of a first degree, pursuing postgraduate qualifications (Author A, 2009). Studies that have focussed on the strategies of Asian students, specifically, have also pointed to the important place of studying abroad (or 'educational mobility') as a further strategy in this pursuit of distinction (Ong, 1999; Bodycott, 2009; Singh and Doherty, 2008). For example, Author B’s (2007) work on Hong Kong nationals who move abroad for degree-level study has shown clearly the advantages that accrue on their return home. Indeed, she argues that as well as the various useful attributes and abilities that are developed during a period abroad, the common culture of their education 'provides the foundation for an exclusive and “elite” group identity’ (p.478). Similarly, Rivzi (2000) has argued that Malaysian employers attach a particularly high status 
to overseas qualifications and, thus, the primary objective of many Malaysian students who move to Australia for university is to obtain a well-recognised qualification that will enable them to secure a good job on their return home.

Given that there is now some evidence that the number of UK students enrolling on a degree programme overseas is increasing (Clark, 2006; Institute of International Education, 2009; Shepherd, 2006), albeit from a rather low base, this article explores the extent to which an overseas education can be seen as part of a broader strategy on the part of British students to seek distinction within the labour market, and whether such an education does indeed offer tangible employment benefits. In developing this analysis, the article also considers the congruence between the experiences of UK students who have studied abroad and the assumptions of various politicians and policymakers which underpin the current policy focus on gaining overseas experience through higher education.

\section{Policy context}

\section{National and regional imperatives}

Traditionally, the UK higher education sector’s ‘internationalisation’ strategy has been motivated by a perceived need to maximise the number of overseas students coming to Britain to pursue undergraduate and/or postgraduate studies. In part, this has been driven by significant decreases in government funding for universities from the 1980s onwards and an increasingly buoyant international student market (Sidhu, 2006; Rizvi and Lingard, 2010). The 'Prime Minister's Initiative on International Education' (commonly known as 'PMI') for example, which ran from 1999 until 2004, set challenging targets in this respect - including 
increasing the UK’s market share of overseas students by 75000 by 2005. Although such strategies have, on the whole, been successful (for example, the PMI target was achieved ahead of schedule), they have also largely defined the way in which UK higher education has come to be seen by many 'sending' countries. Indeed, Sir Drummond Bone, the former vicechancellor of Liverpool University and a key government adviser on the internationalisation of higher education has argued that:

From the point of view of overseas governments and perhaps at least as importantly the press overseas, the main problem with the UK is a perception that our universities are solely interested in international students as a source of revenue. (2008, p.3)

More recently, UK policy is this area has undergone a subtle yet significant shift. Greater weight has come to be placed on the outward mobility of UK students and the advantages such mobility offers to the country as a whole, as well as the individuals concerned. Bone (2008), for example, has argued strongly that the government should 'avoid the temptation of short-term mass recruitment to traditional study in the UK’ (p.1), contending that placing emphasis, instead, on outward student mobility is 'surely desirable in its own right from the UK's national standpoint, networks built overseas by home students being just as valuable as networks built in the UK by overseas students' (p.7). An important contention of Bone - and others who make similar claims - is that the intercultural skills young people develop through studying in another country are of benefit to employers in the UK and help to further the employment prospects of the students who take up these opportunities. Such arguments have underpinned the second phase of the Prime Minister’s Initiative ('PMI2’) (from 2006-2011), in which much greater emphasis has been put on measures to encourage UK students to spend part of their degree overseas through the development of inter-institutional partnerships. They 
are also evident in the framework for higher education (Higher Ambitions) published in the autumn of 2009. Indeed, this states that:

There is a vital role for universities in helping to internationalise the experience of British students, so that they emerge from higher education with a clear sense of Britain's European and global context. Spending even a short period abroad as a student helps individuals develop new perspectives. (BIS, 2009, p. 90)

Similar trends can be seen in other Western countries which have, traditionally, been seen primarily as ‘destination’ countries and focused most energy on promoting inward mobility. In the US, for example: the Abraham Lincoln Study Abroad Fellowship Program has called for the number of Americans studying overseas to be increased to one million by 2016; Harvard University has announced that study abroad will become a requirement for the majority of its degrees; and the University of Minnesota has set a goal for 50 per cent of its students to spend part of their degree programme studying overseas within ten years (CIHE, 2007). Within Australia, both the federal government and individual universities have provided scholarships for home students to study in Asia, while in Canada the Association of Universities and Colleges of Canada has called for the federal government to provide financial support to help an additional 8000 students annually access study or work opportunities abroad (ibid.). Within Europe, similar patterns have been evident: the Austrian government has set a target for 50 per cent of graduates to have had a 'mobility experience' relevant to their studies by 2020, while Finland has set a more modest target - of outgoing student mobility in its universities to have reached six per cent by 2015 (CEC, 2009). More generally, members of the European Union have agreed that, by 2020, 20 per cent of those 
graduating within the 'European Higher Education Area' should have had a period of study or training abroad (ibid.).

At both the national and regional level, the justification for such targets is framed largely, although not exclusively ${ }^{\mathrm{i}}$, in terms of the economic benefits that are held to accrue from educational mobility to the individual and his or her country and region. For example, in 2007, Bill Rammell, the then Minister of State for Higher Education claimed that:

For students, a period of study or work abroad brings positive benefits both personally and professionally. It enhances their understanding of other languages and cultures, and increases their confidence and self-reliance. In a global economy, these skills and competencies are increasingly sought by employers, and students with this experience will find that their employability is higher than without it. (CIHE, 2007, p.1)

The more recent higher education strategy document Higher Ambitions (BIS, 2009), echoes such claims, although situating them within what can be seen as a rather neo-colonial framework:

Internationalisation offers clear economic benefits to the UK. It provides an avenue for spreading UK and European values overseas. It increases our ability to influence a wide range of agendas. It helps us to achieve our domestic policy goals, not just for higher education but across a range of fronts. (p.91)

Similar discourses are also evident at the European level, and are articulated particularly clearly in the 2009 Green Paper on 'Learning Mobility’: 
Studies confirm that learning mobility adds to human capital, as students access new knowledge and develop new linguistic skills and intercultural competences. Furthermore, employers recognise and value these benefits..... It can also strengthen Europe's competitiveness by helping to build a knowledge-intensive society, thereby contributing to the achievement of the objectives set out in the Lisbon strategy for growth and jobs....The mobility of learners should form part of a renewed drive to build Europe's skills and ability to innovate and compete at international level. (CEC, 2009, p.2)

Here, the economic and employment-related benefits to the region are highlighted, alongside those to the individual and his/her nation-state.

\section{The stance of employers}

Despite the clear emphasis on the employment-related benefits of student mobility (such as developing intercultural competence and new linguistic skills) evident within policy documents at both the national and European level, there is less consensus about the attitudes and behaviour of those involved in recruiting graduates. Firstly, some have argued that employers are already acutely aware of the benefits of a period studying abroad, and that this often informs their recruitment practices. The Council for Industry and Higher Education (CIHE), for example, has suggested that, when asked to compare a UK graduate who had completed their full degree overseas with a UK-educated graduate with the same academic qualifications, one in six employers indicated completing a full degree overseas made the candidate more employable (Archer and Davison, 2007). The CIHE goes on to claim that one third of employers viewed a graduate with any overseas study experience as more 
employable, and that the majority of employers who took part in their survey 'commented that studying overseas makes an applicant well-rounded in terms of skills, experience and personal development' (Archer and Davison, 2007, p.14). It is, however, often argued that employers and businesses have to do more to communicate their views to students. The CIHE notes that the message about enhanced employability and attractiveness to major businesses ‘is not getting through’ (CIHE, 2007, p.2), while Sir Drummond Bone (2008) argues that both careers advisers and businesses themselves have to do more to promote educational mobility:

Careers advice is central to the whole internationalisation project since the fundamental assumption is that in the global village, markets are international, sources of supply are international, and careers are international...If students do not understand the international context, there is no fundamental reason why, other than in countries where there is a shortage of capacity, international education should be seen as desirable. (p.5)

Employers have a responsibility to work in their own long-term interests in a global market, by providing placement opportunities, and by giving forward-looking careers advice. (p.16)

It is also the case that some policy documents have raised questions about the extent to which employers do, in practice, value overseas education. Indeed, the European Green Paper on Learning Mobility argues that 'businesses need to be convinced' (CEC, 2009, p.17) of the value of educational mobility. Moreover, even the CIHE report, discussed above, indicates that while a third of employers considered that employability was enhanced by any overseas experience, a significant majority of employers (the remaining two-thirds) did not share this view. Similarly, research that has been conducted on the professional value of the 'Erasmus' 
scheme has indicated that, as participation has become more widespread, the associated employment premium has declined (Bracht et al., 2006).

The subsequent sections of this article seek to explore whether educational mobility does provide UK graduates with a greater competitive edge within a UK (and potentially global) labour market as claimed by many of the policy texts cited above and, thus, whether going overseas for higher education can be considered a further strategy in the pursuit of 'distinction'.

\section{Research methods}

The arguments developed in this article draw on research that was conducted as part of a British Academy-sponsored project on 'International Higher Education and the Mobility of UK Students'. Although there is now a substantial literature on students who move from nonEnglish speaking to English-speaking countries, we know relatively little about the motivations and experiences of those who move from advanced English-speaking nations to pursue their studies elsewhere. Moreover, those studies that have focused on such migration, have tended to focus on 'credit mobility' (i.e. short-term periods abroad as planned parts of a domestic degree programme), such as the Erasmus scheme, to the neglect of those who move overseas for the whole of an undergraduate or postgraduate degree ('degree mobility'). In seeking to address this gap, we conducted in-depth interviews with 85 young adults who had recently completed a degree at an overseas university or were seriously contemplating moving abroad for this reason ${ }^{\mathrm{ii}}$. We were keen to explore any differences by level of study and so included both undergraduates and postgraduates in the sample (see Table 1 for further details). 
[Insert Table 1 here]

Respondents considering overseas education were recruited through a wide variety of means including: mailings and phonecalls to schools and careers offices; a visit to a higher education fair organised by the Fulbright Commission; email and intranet advertisements at the universities of Surrey, Liverpool and Leeds; and Facebook groups. Young adults who had completed an overseas degree were recruited through: contact with 65 alumni associations of overseas universities and the Canadian Rhodes Scholars Foundation; the directory of past scholars, published by the Commonwealth Scholars Commission; mailings and phonecalls to the human resources department of companies listed within the FTSE 100 Index ${ }^{\mathrm{iii}}$; advertisements circulated to staff at a number of universities; and 'snowballing' via our own personal contacts. Our achieved sample is relatively diverse in terms of gender (see Table 1) and ethnicity: 22 of the respondents came from minority ethnic backgrounds. The social class of the sample is, however, much more homogeneous, with a majority from middle class backgrounds (measured in terms of parental education and occupation). However, as other studies have pointed out, those from more privileged backgrounds are currently more likely than others to study overseas - because of: the greater economic resources they are able to draw upon to finance such mobility; their greater familiarity with overseas cultures, often gained through family travel; and, in some cases, their more geographically dispersed social networks (see, for example, Findlay et al., 2006; Kenway and Fahey, 2007; Ong, 1999). As we have argued elsewhere (Authors, 2009), we do not consider this imbalance to be an artefact of our sampling methods ${ }^{\text {iv }}$. 
Individual interviews were conducted with the 85 young adults between September 2007 and February 2008. These asked about their previous educational history, family background, their reasons for becoming interested in overseas education and their decision-making processes. They were also asked about their previous experiences of travel and their assessment of the similarities and differences of higher education in the UK and abroad. Those who had completed an undergraduate or postgraduate degree overseas were also asked about their experiences during their degree (both academic and social) and their lives since graduating. For this group, we were particularly interested in the extent to which they perceived they had been advantaged or disadvantaged within the labour market, as a consequence of their overseas qualification. In the following sections of the article, we draw on this dataset to consider, firstly, the role of employment-related factors in an initial decision to study abroad and, secondly, the perceived impact of an overseas education on labour market experiences. We then go on to explore the ways in which, for some of our respondents, an overseas education and early employment experiences both fed into a longerterm goal of securing citizenship of another country.

\section{Making a decision: the relative importance of employment-related factors}

Many studies of 'East' to 'West' migration have emphasised the key role of calculations about future employability in decisions about whether to study abroad; to students from Asian countries, in particular, an overseas qualification is frequently seen as conferring substantial advantage within domestic labour markets, once they have returned home (Bodycott, 2009; Rizvi, 2000). In her research on mobility from Hong Kong to Canada for higher education, for example, Author B (2007) argues that many Hong Kong employers have themselves been educated overseas and so, when recruiting graduates, often favour others in possession of a 
Western degree. In this way, she argues, privilege is perpetuated. There is some evidence that participation in the European Union's Erasmus programme may also be underpinned by a desire to improve one’s employment prospects. Indeed, Krazaklewska (2008) argues that the motives of Erasmus students tend to relate to two dimensions: an 'experiential' dimension (encompassing a range of personal and cultural factors) and an 'employment' dimension (including: a belief that a period abroad will lead to an improvement in marks on return to the home university; the development of international openness; and a greater appeal to potential employers).

In our research, however, the absence of such motivations was notable. There was little evidence to suggest that our respondents had sought an overseas education as a strategic means of accumulating cultural capital and securing labour market advantage. Indeed, many of the young adults in our sample described how their career plans had been very vague and they had given little consideration to the potential impact of a period abroad on their employability:

I don't really have like any kind of great long-term career plans, I'd say I'm kind of like, I want to do this and see like what avenues it opens up and see where I go from there. (Idris, considering MA abroad)

To be honest I'm not sure, looking back on it [overseas study] I'm not sure that I actually saw it as a long-term sort of plan, I think I just wanted, because the course looked interesting and I just wanted to go and live somewhere different for a while, I hadn’t, I didn't really think through what I'd do after I'd done the Master's degree, so 
I'm not sure there was really that degree of strategic thought of looking into it! (Hayley, MA, Joensuu University, Finland)

To be perfectly honest I wasn’t very much thinking about advantage, I mean I was quite interested in studying longer and I wanted to travel and so it was an end in itself. I don't think I gave much thought to the fact you know where would I end up at the end of it? (Shaun, postgraduate study in Canada and at European Union Institute, Italy)

In explaining the differences between our sample and research conducted to date, we suggest, firstly, that despite the ostensibly 'care-free’ objectives of many of our respondents (such as seeking 'excitement' and 'adventure' from overseas study), most came from highly privileged backgrounds and their experiences served only to facilitate the reproduction of their privilege (Authors, 2010). Secondly, in the cases where students were clearly adopting a more strategic outlook, this was in relation to the status of the higher education institution they attended, rather than the possession of an overseas qualification per se. Indeed, as we have argued elsewhere (Authors, 2009), a significant number of our respondents chose to move overseas only when they perceived that access to elite education (particularly entry to Oxford and Cambridge) within the UK had been closed down. Moreover, when those in our sample who had already completed a degree overseas were asked to reflect on their labour market experiences, several remarked on the value of the awarding institution, rather than its 'overseas' location. In this extract, for example, Nicola, who gained a bachelor's degree from Harvard University, asserts that, for her, it was the status of the university that was most advantageous, rather than the experience of having studied outside the UK in itself: 
I mean I think the career I have now is very different from what I would have had, had I studied in England. It's kind of hard to tell what would have happened. Obviously I probably wouldn't be in Washington DC. I don't know if I'd be in kind of the environmental field. But kind of going to Harvard, that's a big plus on a CV you know, at the top of the resumé, so that's probably helped quite a lot!

This kind of reasoning is also partially explained by the significant spatial variation in the value of educational qualifications. The evidence suggests that a degree awarded by a 'Western', Anglophone country often has considerably higher status within the labour markets of many 'Eastern' countries than an equivalent domestic qualification; this then provides strong motivation to seek such advantage through overseas study. In contrast, in those countries such as the UK from where prestigious degrees often emanate, calculations are clearly different; indeed, an overseas qualification may be seen by employers as of less value than one secured from a British university. There is some evidence that similar geographical variation can be seen even within Europe, with the 'professional value' of the Erasmus scheme being valued higher by students in eastern European countries than by their counterparts in western nations (Bracht et al., 2006). This argument is developed further below.

\section{Moving into employment: the impact of overseas study}

In their study of the leaders of global companies, Mazlish and Morss (2005) argue that these 'global elites' 'increasingly see themselves as cosmopolitans, as global citizens, with an identity that embraces but that also transcends the nation-state and its restricted sense of territoriality’ (p.171). They also suggest that there is a clear route from some forms of 
international education into high status multinational companies. Indeed, they note that McKinsey (the management consultancy firm) boasts that it is the largest employer of Rhodes and Marshall scholars on the planet. Moreover, Recchi (2006) points to a link between participating in intra-European educational mobility programmes and securing positions of influence within the EU, suggesting that the institutions of the European Union tend 'to favour the way of life of mobile, well-resourced and well-educated Europeans who have participated in Erasmus exchange programmes and developed a cosmopolitan outlook' (p.72). Certainly, within our study, those respondents who had been keen to work in an international arena believed that having studied abroad had given them an advantage over other graduates with no overseas experience. Many of those working in academia also expressed similar views. Nevertheless, these were the only two areas of employment in which those in our sample were able to identify a specific and direct employment-related benefit to having studied overseas.

Indeed, our research suggests that, not only were relatively few of our respondents motivated to pursue an overseas education because of strategic calculations about labour market advantage but that, in a significant minority of cases, overseas study was believed to have impeded job prospects. This was played out in a number of ways. Firstly, some talked about the ways in which the longer length of postgraduate qualifications outside the UK had delayed their entry into the labour market and disadvantaged them at the initial stages of their career, at least in comparison to their peers who had remained in Britain:

So yeah I've often thought I could be a lot further on in my career actually had I not gone to UBC... I think that's as well because you know the Master's is two years, two 
years for a Master's, you know that's two thirds of a $\mathrm{PhD}$ here and all you've got is a Master’s. (Ralph, MA, University of British Columbia, Canada)

Secondly, some respondents believed that, as careers advice remains quite nationallyoriented, the support they received while studying abroad did not prepare them well for entry into the British labour market. This was commented upon by Fergus, who studied for a Master's degree at the Australian National University:

They [course director and other teaching staff] have provided advice to an extent about, you know, applying for various things. But obviously their focus is on Australia and Australian students and things. So it's a bit difficult for them to comment on the British civil service etc.

Thirdly, and in contrast to the claims made in the policy documents discussed in the first part of this article, many respondents believed that UK employers often did not value a period of overseas study. Some described a relatively high level of ignorance on the part of graduate recruiters about overseas qualifications. Yuuna, for example, described the effort that she had had to put in to convince employers that her degree, obtained from an Ivy League college in the US, was of equivalent value to a British degree, while Divyesh, who had studied in South Africa, believed that such views were often predicated upon an assumption that British degrees were of a higher quality than those obtained elsewhere:

Oh well, I mean again the thing about English university is that it's bog standard, they [employers] know exactly what English universities are, whereas America, I have to 
explain what it is and what their classification means and all that stuff. So it's a lot more work for me. (Yuuna, BA, Brown University, US)

I mean, it has delayed my career slightly because as I said when I got back to the UK you know a lot of people were sceptical about the degree, about the fact that I'd decided, that I'd actually chosen to study abroad as opposed to a UK university. Because for me it’s a level of ignorance, it's like ‘Well, if you don’t study in the UK then you don’t get a quality education' - well, that's not the case you know! I did get a quality education but how do you influence somebody’s opinion you know? (Divyesh, BA, MA, Rhodes University, South Africa)

Similarly, Alan explained that one of the factors that had discouraged him from moving back to the UK after studying for a psychology degree at the Australian National University was the attitude of British employers:

So, if you were thinking about promotion prospects in the UK, it's actually probably you know a ball and a chain rather than an advantage because it would be really hard to convince the British Psychological Society that my course, the course that I did here, is equivalent to the British ones. (Alan, MSc, Australian National University)

In other cases, respondents described how understandings of university status did not transfer easily across national borders. Leo, for example, had completed a postgraduate qualification at a very prestigious 'grande école' in Paris (following an undergraduate degree at Cambridge). Nevertheless, he had had some difficulty in finding a job on return to the UK and had become frustrated that very few employers were aware of the status of the French 
institution he had attended. From his perspective, no labour market advantage seemed to have accrued through gaining access to an elite and highly selective university abroad. Finally, a small number of the young adults in our sample wondered whether evidence of travelling per se (even in order to pursue a degree) had disadvantaged them in some fields of employment:

Interviewer: Do you think it [an overseas education] impresses big companies or not? Shaun: I doubt it actually. I mean, I’m thinking about law firms. I think law firms tend to be quite pragmatic and I suspect some of them, it depends what sort of firm it is, but some of them I think might be slightly suspicious of the sort who maybe a bit flighty, head in the wrong place, not gonna buckle down for the firm possibly.....That's not really what they're looking for on the CV quite you know, they've no objections to it but I doubt if it's.... I think the advice I'd give is go if you're interested either in what you're studying or in the culture, but not really as a career move. (Postgraduate study at University of Toronto, Canada and European Union Institute, Italy)

Again, the findings from our study illustrate some of the differences between the experiences of students who travel from 'East' to 'West' in pursuit of a higher education and those who move from western, Anglophone nations. Although there is a large body of work within economic geography on the mismatch between human capital and employment opportunities for migrants moving from less developed to developed countries (Bauder, 2003; Boyer, 1996; Iredale, 2003), existing studies of those who move to the 'West' for higher education have highlighted the considerable labour market rewards that frequently follow the acquisition of an overseas tertiary-level qualification (Ong, 1999; Rizvi, 2000; Author B, 2007). In contrast, our work points to the very different value accorded to a degree obtained abroad within the UK labour market. While the extant literature in this area is small, there is some, albeit 
limited, evidence that similar patterns may be found in other European countries. WiersJensen (2008), for example, has argued that Norwegian graduates who have an overseas qualification often face greater difficulties in entering the national labour market than their peers in possession of a degree from a domestic institution. Indeed, on the basis of his sample, he argues that both unemployment and 'over-education' were more prevalent amongst those who had studied overseas. Moreover, analysis of migration within Europe more generally has pointed to the relatively 'risky' nature of this endeavour. Favell et al. (2006) argue that mobile Europeans take 'much more marginalised, risky career decisions compared to those in nationalised careers from welfare states with stable pay-offs at home' (p.9). They go on to suggest that, because of this level of risk, mobility is more likely to be pursued by so-called 'social spiralists' than their peers from more privileged backgrounds. Indeed, they contend that:

the 'so-called 'elites', who have opted to be move internationally under present conditions of globalisation, are often not from elite backgrounds but provincial, career-frustrated 'spiralists' who have gambled with dramatic spatial mobility in their education and careers abroad to improve social mobility opportunities that are otherwise blocked at home. (p.9)

Our study also highlights the way in which cultural capital cannot always be carried unproblematically across national borders (see also Gewirtz et al., 1995). Despite the prevalence of world rankings of universities (Marginson and van der Wende, 2007), an increasingly international market for higher education (Altbach and Knight, 2007) and the alleged globalisation of education policy (Montsios, 2009), the strongly national orientation of many British employers is evident. Narratives such as those presented above suggest that, 
as a result of a lack of knowledge of other higher education systems on the part of many UK employers and perhaps pervasive assumptions that a British degree is of greater value than an equivalent-level qualification gained elsewhere, the employment benefits of studying at an elite overseas university are often highly geographically circumscribed.

\section{'Flexible employment'?}

In her much-cited text, Flexible Citizenship (1999), Aihwa Ong argues that contemporary society has witnessed a considerable shift in the meaning attached to the concept of citizenship. She claims that this has occurred, mainly, in response to various globalising pressures. Indeed, she contends that:

\footnotetext{
Although citizenship is commonly thought of as based on political rights and participation within a sovereign state, globalization has made economic calculation a major element in diasporan subjects’ choice of citizenship...seeking to both circumvent and benefit from different nation-state regimes by selecting different sites for investments, work and family relocations. (p.63)
}

She goes on to suggest that citizenship can thus be considered as a strategy for acquiring capital and/or power. It is 'flexible' in that it is driven largely by economic concerns, and implies little loyalty to any one particular nation-state. The role education can play in such strategic behaviour is also discussed explicitly by Ong. Indeed, she claims that student migration from Hong Kong to universities in various western, Anglophone nations (the focus of her empirical work) has often been driven by economic imperatives; here, the acquisition of citizenship - which overseas study may facilitate - is rarely a goal in its own right. Instead, 
it is understood primarily as a means of gaining employment overseas and contributing to capital accumulation. Such motivations can also be seen in recent research on students from Asia and the Indian sub-continent who move to Australia to pursue their higher education (Jackling, 2009; Robertson, 2009). Baas (2006) argues that a large majority of mobile Indian students are motivated by a desire to secure permanent residency - in part, encouraged by the immigration policies of the Australian government (see also Ziguras and Law, 2006). As in Ong's analysis, education is seen as a means of gaining residency which, in turn, is believed to open up new employment opportunities and other means of securing economic advantage. Indeed, Baas suggests that most such students are from families which 'are upwardly mobile but often seem to think that their mobility is too limited in India itself....having a family member abroad will not only generate more money but will also increase the family’s reputation’ (p.23).

In our study, however, a markedly different picture emerged. Many of our respondents (both undergraduate and postgraduate) had embarked upon overseas education because of a strong desire to live abroad on completion of their studies as an end in itself, rather than as a means to better employment opportunities. Amongst this group, it was commonly believed that, in order to gain citizenship of their chosen country, it would first be necessary to find employment in that country, and that gaining an overseas qualification would facilitate this process. Indeed, many believed that employers in their desired country of residence would look much more favourably on those with a degree from a 'domestic' university, rather than one gained in the UK. This is illustrated well in the following quotation from Cecil:

I got a girlfriend in Munich who was German and she was more or less attached to Munich because of her job, she can’t really leave Bavaria. And I knew that, you 
know, if I was going to stay in Germany to be with her, I didn’t want to be an English teacher forever, that was $100 \%$ clear to me, and I knew I needed something else under my belt. To go to a German employer and say right, I've got a BA from England in a non-business subject, you know you can expect your CV to go in the bin more or less straight away, it’s too difficult for them to deal with. And I knew I needed something from Germany so I could prove look I’m capable of working in German, I’m capable of understanding business subjects in German and the idea was then OK well let's do this MA, let's do it part-time, let's teach English alongside that so I can earn enough money to survive and then once the MA is done, let's go out and try finding the dream job in Germany. (Cecil, MA, University of Applied Sciences, Munich, Germany)

Here, we see perceived causality working in the opposite direction from that outlined by Ong: our sample saw employment overseas as a necessary step towards securing citizenship, rather than citizenship as a strategic means of gaining employment or securing economic advantage. Like Ong’s respondents, overseas education played an important role in this process. However, it was largely in facilitating entry to overseas employment as a step towards the more important goal of securing citizenship, rather than as a means of acquiring a 'flexible citizenship’ necessary for capital accumulation. Thus, we would argue that it is employment that was pursued strategically, in a 'flexible’ manner, rather than citizenship.

Our work thus suggests that there may be further important differences between the way in which mobility for higher education is understood by those moving to western, Anglophone nations and those who are moving from such countries. While our sample is clearly composed of only UK citizens and thus does not enable us to generalise to other Anglophone nations, we suggest that the difference between our findings and those of previous work in this area may 
be explained by variations in the students' country of origin. UK students are perhaps less likely than their counterparts from China, Hong Kong, Malaysia and the Indian sub-continent, for example, to believe that economic opportunities per se will be greater abroad. Instead, it is the appeal of alternative ways of life and different cultural values that entice ${ }^{\mathrm{v}}$. Such sources of motivation are certainly evident in the narratives of our respondents, as the following examples illustrate:

I’ve always loved America from being a child, a young child. I think from what you've seen on films and because it's all Hollywood films that I watched growing up, you always wanted to be a part of the movies, so I've always wanted to go to America and never seen anything bad, I've always looked at it through like rose-tinted spectacles. (Dwight, considering undergraduate study in the US)

It's more the idea of like being able to be a lawyer in the United States, you know, like the whole lifestyle and stuff, the culture, the big cities and like New York, Washington. (Oliver, considering undergraduate study in the US)

Implicit in such narratives is also a belief that higher education qualifications are not easily portable, and that employers continue to value those that are acquired within their own country. While we have argued in previous sections that UK employers are often not particularly welcoming of qualifications gained overseas, our data suggest that employers in other western countries may share similar views. Alan, for example, believed that his degree from an Australian university had been key to securing employment in Australia on completion of his studies: 
Well, certainly in the fact that I now have an Australian qualification and a recent one helps in the line of work that I'm doing now, helped me get the job......having the local qualification definitely helps. (Alan, MSc, Australian National University)

Again, this raises important questions about some of the claims made in the policy texts discussed in the first part of this article about the increasingly global nature of the graduate labour market and the willingness of employers to seek talent from across the globe, irrespective of the particular country from which qualifications have been gained. Our data suggest that graduate employers often remain predominantly national in focus and, perhaps largely as a consequence of this, young adults continue to see the value of higher education qualifications as strongly spatially-differentiated. As such, there appear to be strong parallels between our research and studies within economic geography that have emphasised both the spatiality and the social basis of credential evaluation (e.g. Iredale, 2003).

\section{Conclusion}

In her analysis of higher education marketing strategies across the globe, Ravinder Sidhu (2006) argues that: 'The global education market draws on, and simultaneously authors, the fantasies, dreams and desires of its customers.... Establishing oneself as interesting and different marks out the tourist-student as an object worthy of recruitment and further investment' (p. 308). However, as we have demonstrated above, our in-depth study of the motivations of UK students leads us to rather different conclusions. Unlike the research which has been conducted on Asian students, we found little evidence of the strategic pursuit of labour market advantage through overseas education. Nevertheless, this is not to say that the young adults in our sample had not acted strategically at all: for some, an overseas education 
represented a first step towards gaining employment within and, ultimately, citizenship of, another country. Moreover, as we have argued elsewhere (Authors, 2009), a significant minority used overseas education to gain access to a high status education that they believed had been closed down to them in the UK. Even in these cases, however, obtaining an elite education elsewhere did not lead automatically to reward within the British labour market. The cultural capital that perhaps would be assumed to accumulate from attending an Ivy League college in the US or a 'grande école' in France did not necessarily transfer across national borders in an unproblematic manner.

Indeed, in developing this argument, we have pointed to the important spatial disparities that our research has revealed. While extant research on educational mobility from 'East' to 'West' has emphasised the global nature of the higher education market, our study suggests that the motivations and experiences of western students are significantly different from those of their Asian counterparts, and that more attention needs to be paid to these significantly different geographies of student migration. Indeed, the problems faced by our respondents in gaining recognition for their overseas qualifications - even if obtained from highly elite institutions - illustrate the limited 'portability' of educational qualifications in some parts of the world. These differences between the experiences of students who move to the UK (and other western countries) and those who move from the UK can be explained, in large part, by the positioning of UK degrees, relative to those awarded by other countries, and the relative positioning of western bodies of knowledge. The available evidence suggests that Asian employers, for example, often value a western degree more highly than one obtained from a domestic university - because of: its content, favouring western forms of knowledge (Rizvi, 2000); its association with the development of western forms of 'comportment' (Author B, 2008); and the status of western universities, generally, on the world stage. In contrast, the 
value of an overseas degree to a UK employer is significantly different: the hierarchical positioning of universities internationally (Marginson, 2008) and the privileging of western, Anglophone forms of knowledge (particularly in the disciplines of management, commerce and economics) (Mazlish and Morss, 2005; Kenway and Fahey, 2007) may both encourage assumptions amongst graduate recruiters about the 'superior' quality of a UK qualification. Such assumptions clearly stand in stark contrast to the policy discourses discussed in the first part of this paper and highlight important disparities between the very positive view of higher education, made explicit in formal texts from UK politicians, the European Commission and the UK-based Council for Industry and Higher Education, and the actual practices of many graduate employers. Claims that a truly global graduate labour market has arrived thus seem a little premature.

\section{Acknowledgements}

We would like to thank the British Academy for funding the study upon which this article is based and the respondents who gave up considerable amounts of their time to talk to us.

\section{References}

Altbach, P. and Knight, J. (2007) The Internationalization of Higher Education: motivations and realities, Journal of Studies in International Education, 11, 3-4, 290-305.

Archer, W. and Davison, J. (2007) Graduate Employability: what do employers think and want? London, Council for Industry and Higher Education. 
Baas, M. (2006) Students of migration: Indian overseas students and the question of permanent residency, People and Place, 14, 9-24.

Bauder, H. (2003) 'Brain abuse’ or the devaluation of immigrant labour in Canada, Antipode, 35, 4, 699-717.

Bodycott, P. (2009) Choosing a higher education study abroad destination. What mainland Chinese parents and students rate as important, Journal of Research in International Education, 8, 3, 349-373.

Bone, D. (2008) Internationalisation of HE: a ten-year view. Submission to the Department for Industry, Universities and Skills Debate on Higher Education Available at: http://www.bis.gov.uk/wp-content/uploads/2009/10/HE-Internationalisation-Bone.pdf (Accessed 21 December 2009).

Boyer, T. (1996) Problems in paradise: Taiwanese immigrants to Auckland, New Zealand, Asia Pacific Viewpoint, 37, 1, 59-79.

Bracht, O., Engel, C., Janson, K., Over, A., Schomburg, H. and Teichler, U. (2006) The Professional Value of Erasmus Mobility European Commission, DG-EAC.

Brown, P. and Hesketh, A. (2004) The Mismanagement of Talent. Employability and Jobs in the Knowledge Economy Oxford, Oxford University Press.

Clark, T. (2006) A free lunch in Uppsala, The Guardian, 24 October 2006. 
Commission of the European Communities (CEC) (2009) Promoting the Learning Mobility of Young People COM (2009) 329 Final. Brussels, Commission of the European Communities.

Council for Industry and Higher Education (CIHE) (2007) Global Horizons for UK Students. A guide for Universities Available at: http://www.ciheuk.com/docs/PUBS/0707GLOBAL.pdf (Accessed 12 November 2007).

Department of Business, Innovation and Skills (BIS) (2009) Higher Ambitions. The future of universities in a knowledge economy London, Department of Business, Innovation and Skills.

Favell, A., Feldblum, M. and Smith, M. (2006) The Human Face of Global Mobility: a research agenda. In: Smith, M. and Favell, A. (eds) The Human Face of Global Mobility New Brunswick, Transaction Publishers.

Findlay, A. and King, R. (2010) Motivations and Experiences of UK Students Studying Abroad BIS Research Paper No.8, London, Department for Business, Innovation and Skills.

Findlay, A., King, R., Stam, A. and Ruiz-Gelices, E. (2006) Ever reluctant Europeans. The changing geographies of UK students studying and working abroad, European Urban and Regional Studies, 13, 4, 291-318.

Gewirtz, S., Ball, S. and Bowe, R. (1995) Markets, Choice and Equity in Education Buckingham, Open University Press. 
Institute of International Education (2009) Open Doors 2009 Country Fact Sheet: United Kingdom Available at: http://opendoors.iienetwork.org/?p=150860 (Accessed 21 December 2009).

Iredale, R. (2003) International approaches to valuing the professional skills of permanent and temporary migrants. In: Charney, M., Yeoh, B. and Kiong, T. (eds) Asian Migrants and Education: the tensions of education in immigrant societies and among migrant groups London, Kluwer Academic Publishers.

Jackling, B. (2007) The lure of permanent residence and the aspirations and expectations of international students studying accounting in Australia, People and Place, 15, 3, 31-41.

Kenway, J. and Fahey, J. (2007) Policy incitements to mobility: some speculations and provocations. In: Epstein, D., Boden, R., Deem, R., Rizvi, F. and Wright, S. (eds) Geographies of Knowledge, Geometries of Power: Framing the Future of Higher Education World Yearbook of Education 2008 New York, Routledge.

Krzaklewska, E. (2008) Why study abroad? An analysis of Erasmus students’ motivations. In: Byram, M. and Dervin, F. (eds) Students, Staff and Academic Mobility in Higher Education Cambridge, Cambridge Scholars Publishing.

Marginson, S. (2008) Global field and global imagining: Bourdieu and worldwide higher education, British Journal of Sociology of Education, 29, 3, 303-315. 
Marginson, S. and van der Wende, M. (2007) To Rank or To Be Ranked : the impact of global rankings in higher education, Journal of Studies in International Education, 11, 3-4, 306-329.

Mazlish, B. and Morss, E. (2005) A Global Elite? In: Chandler, A. and Mazlish, B. (eds) Leviathans. Multinational Corporations and the New Global History Cambridge, Cambridge University Press.

Montsios, S. (2009) International organisations and transnational education policy, Compare, 39, 4, 469-81.

Ong, A. (1999) Flexible Citizenship: the cultural logics of transnationality Durham, Duke University Press.

Reay, D., David, M. and Ball, S. (2005) Degrees of Choice. Social class, race and gender in higher education London, Trentham Books.

Recchi, E. (2006) From Migrants to Movers: citizenship and mobility in the European Union. In: Smith, M. and Favell, A. (eds) The Human Face of Global Mobility New Brunswick, Transaction Publishers.

Rizvi, F. (2000) International Education and the Production of Global Imagination. In: Burbules, N. and Torres, C. (eds) Globalisation and Education. Critical Perspectives New York, Routledge. 
Rivzi, F. and Lingard, B. (2010) Globalizing Educational Policy London, Routledge.

Robertson, S. (2009) Student switchers and the regulation of residency: the interface of the individual and Australia's immigration regime, Population, Space and Place, Advance online publication.

Shepherd, J. (2006) UK Students Drawn to US for Broad-Based Degrees, Times Higher Education Supplement, 4 August 2006.

Sidhu, R. (2006) Universities and Globalization. To market, to market. New Jersey, Laurence Erlbaum Associates Ltd.

Singh, P. and Doherty, C. (2008) Mobile students in liquid modernity. Negotiating the politics of transnational identities. In: Dolby, N. and Rizvi, F. (eds) Youth Moves. Identities and education in global perspective New York, Routledge.

Wiers-Jenssen, J. (2008) Does higher education attained abroad lead to international jobs?, Journal of Studies in International Education, 12, 2, 101-130.

Ziguras, C. and Law, S-F. (2006) Recruiting international students as skilled migrants: the global ‘skills race’ as viewed from Australia and Malaysia, Globalisation, Societies and Education, 4, 1, 59-76. 
Table 1: Composition of the sample

\begin{tabular}{lcccc}
\hline & $\begin{array}{c}\text { Sixth-formers } \\
\text { considering an }\end{array}$ & Those who had & Undergraduates & Those who had \\
& completed an & considering a & completed a \\
& degree overseas & degree overseas & degree overseas & degree overseas \\
& 12 & 4 & 13 & 19 \\
\hline Male & 8 & 7 & 7 & 15 \\
Female & 20 & 11 & 20 & 34 \\
Total & & & & \\
\hline
\end{tabular}

${ }^{\mathrm{i}}$ In Norway, for example, the government has supported overseas study as a means of responding to fluctuating demand for higher education places (Wiers-Jensen, 2008).

${ }^{\text {ii }}$ As our data collection ended before those considering overseas study were required to make a final decision, we are unable to explore any differences between those who did go on to study abroad and those who did not (see Findlay and King, 2010 for some discussion of differences between these two groups). However, in terms of the arguments advanced in this article, there were no significant differences between those who had completed a degree abroad and those who were seriously considering this option.

iii The FTSE 100 Index (Financial Times Stock Exchange Index) is a share index of the 100 most highly capitalised companies listed on the London Stock Exchange.

${ }^{\text {iv }}$ Research on mobile students from outside the UK has also tended to point to their relatively privileged backgrounds and middle class location. Indeed, many of the studies of Asian students, with which we make comparisons in this article, emphasise the significant cultural and economic resources often available to these young people.

${ }^{v}$ See Authors (2009b) for a further discussion of the ways in which particular overseas countries were valued for their perceived 'difference' from the UK. 